Apidologie, 1984, 15 (1), 63-74.

\title{
MORPHOMETRIC STUDIES ON THE INDIAN HONEYBEE, APIS CERANA INDICA F. EFFECT OF SEASONAL VARIATIONS
}

\author{
V.K. MATTU and L.R. VERMA \\ Department of Bio-Sciences, Himachal Pradesh University, \\ Simla -171005, India
}

\begin{abstract}
SUMMARY
Morphometric studies on the worker bee samples collected during various seasons revealed that many of the morphological characters such as length of flagellum, antenna, fore wing, radial cell, wing veins VL and IL, vannal lobe, femur, tibia, third tergite, wax mirror, third and sixth sternites and breadth of hind wing showed significantly higher values for the samples collected during summer and autumn seasons as compared to those collected in other seasons. However, other morphological characters viz., tongue length, length of scape, hind wing, metatarsus, breadth of fore wing, radial cell etc. did not show any significant differences among bee samples collected during different seasons. Summer and autumn are the periods of maximum honeyflow in this region and it seems that strength of the colony and piesence of surplus food for larvae affect the biometry of A.c. indica.
\end{abstract}

\section{INTRODUCTION}

The well being of a honeybee colony is possible only if annual biological cycle is well adjusted to ecological parameters influencing it. Besides geographic variability, seasonal variations also influence the different morphological features of honeybee. There is a lot of information available on the relationship of geographical position with morphometric characters of honeybees (AlpATov, 1929 ; KAPIL, 1956 ; RutTNER, 1976 ; KShirsagar, 1981) but only a few investigators have studied the effect of seasonal variations on morphometric characters (Michailov, 1927 ; Gromisz, 1962 ; Dianov, 1977).

Present studies deal with the effect of seasonal variations on the biometry of A.c. indica which is an important parameter in racial investigation of honeybees. 


\section{MATERIALS AND METHODS}

Samples consisting of fifteen marked worker bees (25-26 days old) were collected during different seasons of $1980-1981$ from a single colony in the local apiary at Shimla $\left(31^{\circ}-06^{\prime} \mathrm{N}\right.$ latitude, $77^{\circ}-10^{\prime} \mathrm{E}$ longitude and 2206 metres altitude). Worker bees were reared on combs having the same sized brood cells ( 22 cells in four linear inches). Colony was headed by the same mother queen throughout the period of investigation. Bees samples were collected from the experimental colony with the help of aspirator in the months of May (summer); July (rainy season); September (autumn); November (early winter); January (late winter) and March (spring) and were named as summer, rainy, autumn, early winter, late winter and spring season bees. Worker bees were anaesthetized with chloroform, killed in warm water and preserved in Pampell's fixative (RutTnER et al., 1978). All measurements were taken with the help of a stereomicroscope equipped with an ocular scale. Measurements on different wing venation angles were taken with the help of a slide projector.

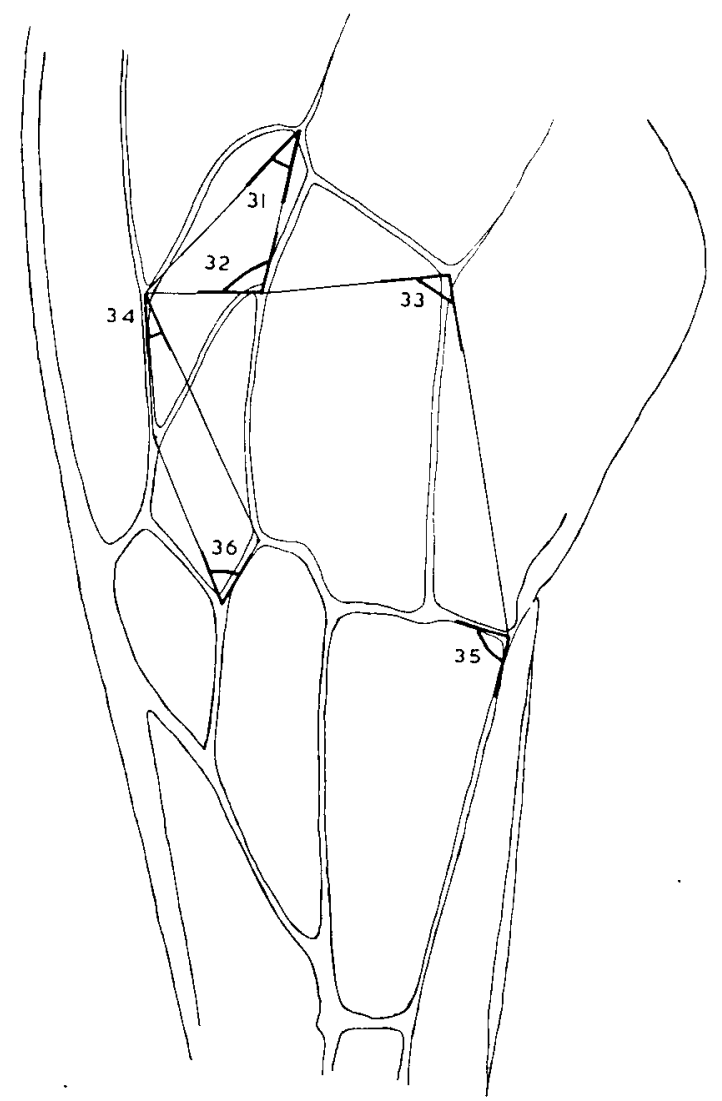

FIG. 1. - Different wing venation angles (31 to 36) studied in the present investigations

Different morphometric characters studied in the present investigations were tongue length; length of scape, pedicel, flagellum and antenna; length and breadth of fore wing and radial cell; length of 1 st and 2 nd abscissa of vein $\mathbf{M}_{3+1}$ in cell $2 \mathrm{~m}$; different wing venation angle numbers 31 to 36 (fig. 1); length and breadth of hind wing; length of veins RL, ML, VL 
and IL (fig. 2); number and extent of hamuli; length of jugal and vannal lobes; length of femur, tibia and metatarsus; breadth of metatarsus; length of third and fourth tergites; length and breadth of wax mirror; distance between wax mirrors; length of third sternite and length and breadth of sixth sternite. The characters studied were based on the previous morphometric work of Alpatov (1929) and Ruttner el al., (1978).

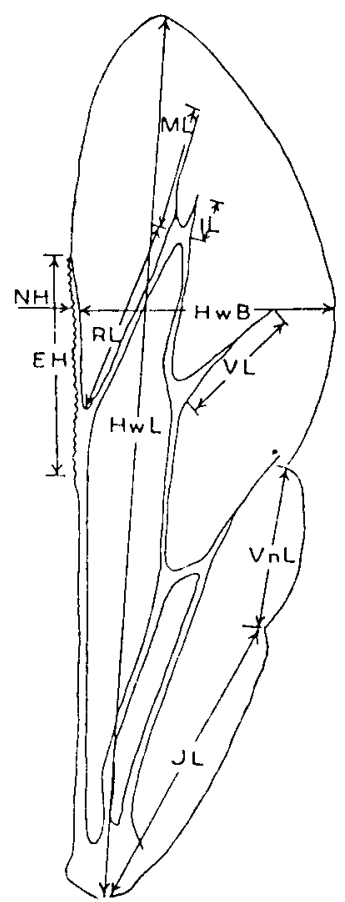

FIG. 2. - Different characters of the hind wing studied in the present investigations

HwL and $\mathrm{HwB}=$ Length and breadth of hind wing.

RL, ML, VL and IL $=$ Length of different veins.

NH and $E H=$ Number and extent of hamuli.

$\mathrm{JL}$ and $\mathrm{VnL}=$ Length of jugal and vannal lobes.

Statistical analysis of the data was made by applying one way analysis of variance and test for testing the significance of results (SNEDECOR and COCHRAN, 1976).

\section{RESULTS}

Results are summarised in tables 1 and 2 and only those morphological characters which showed significant differences are discussed below : 


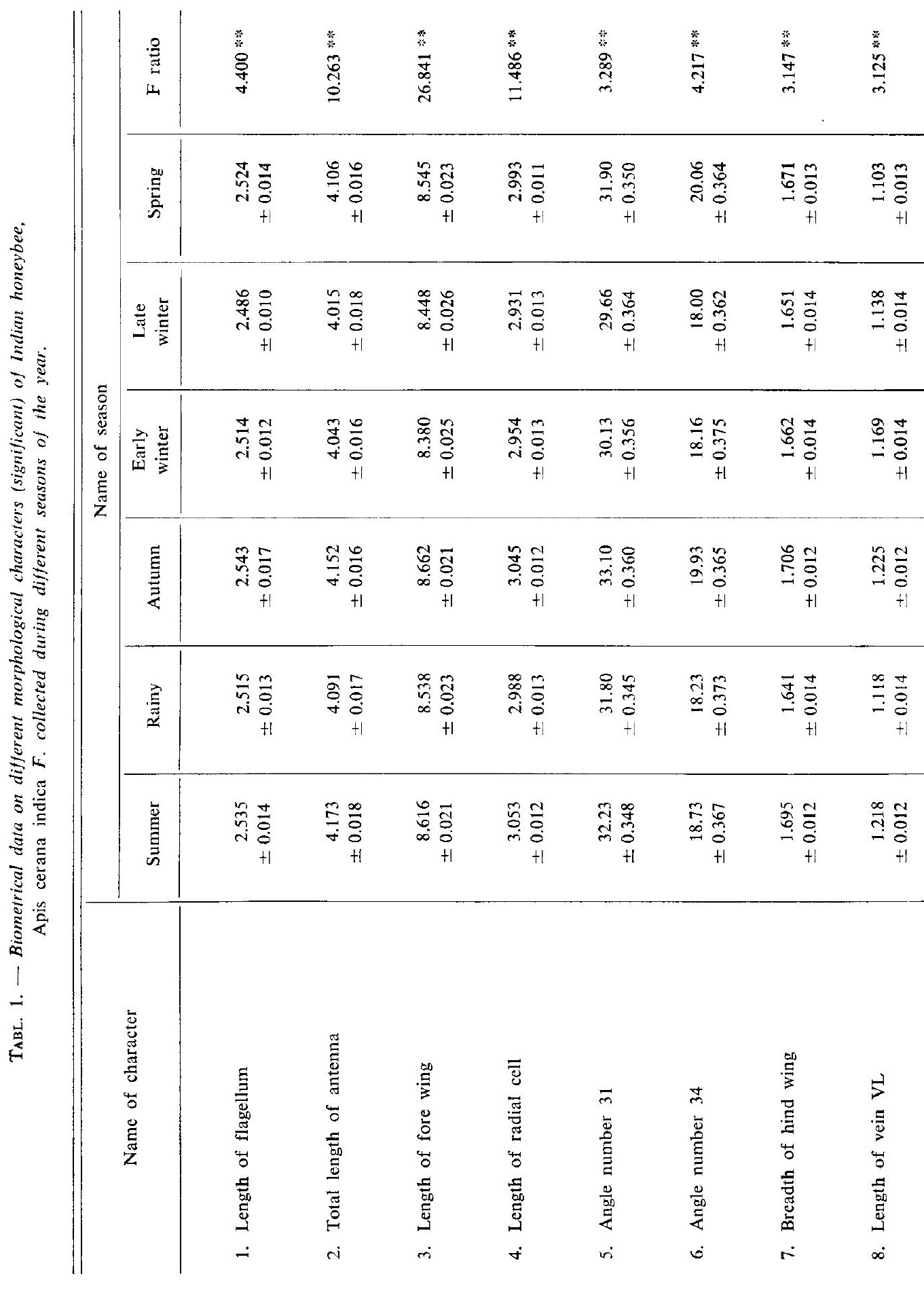


TABL. 2. - Biometrical data on different morphological characters (not significant) of Indian honeybee, Apis cerana indica $F$. collected during different seasons of the year.

\begin{tabular}{|c|c|c|c|}
\hline Name of character & Mean \pm S.E. & R.V. of Means & $\begin{array}{c}\text { Season } \\
\text { with peak } \\
\text { value }\end{array}$ \\
\hline 1. Tongue length & $5.247 \pm 0.167$ & $5.012-5.247$ & Autumn \\
\hline 2. Length of scape & $1.061 \pm 0.016$ & $1.028-1.061$ & Summer \\
\hline 3. Length of pedicel & $0.240 \pm 0.005$ & $0.231-0.240$ & Summer \\
\hline 4. Breadth of fore wing & $2.855 \pm 0.019$ & $2.822-2.855$ & Autumn \\
\hline 5. Breadth of radial cell & $0.417 \pm 0.003$ & $0.408-0.417$ & Autumn \\
\hline 6. Length of $1 \mathrm{st}$ abscissa & $0.523 \pm 0.006$ & $0.516-0.523$ & Summer \\
\hline 7. Length of 2 nd abscissa & $0.139 \pm 0.003$ & $0.134-0.139$ & Summer \\
\hline 8. Angle number 32 & $107.26 \pm 0.770$ & $105.03-107.26$ & Summer \\
\hline 9. Angle number 33 & $93.10 \pm 1.197$ & $89.93-93.10$ & Summer \\
\hline 10. Angle number 35 & $88.73 \pm 0.605$ & $86.50-88.73$ & Summer \\
\hline 11. Angle number 36 & $42.73 \pm 0.543$ & $41.93-42.73$ & Summer \\
\hline 12. Length of hind wing & $5.937 \pm 0.031$ & $5.863-5.937$ & Summer \\
\hline 13. Length of vein $\mathrm{RL}$ & $1.475 \pm 0.014$ & $1.416-1.475$ & Spring \\
\hline 14. Length of vein $\mathrm{ML}$ & $1.238 \pm 0.013$ & $1.197-1.238$ & Autumn \\
\hline 15. Number of hooks & $18.96 \pm 0.347$ & $18.43-18.96$ & Summer \\
\hline 16. Extent of hamuli & $1.248 \pm 0.012$ & $1.228-1.248$ & Summer \\
\hline 17. Length of jugal lobe & $1.790 \pm 0.019$ & $1.750-1.790$ & Summer \\
\hline 18. Length of metatarsus & $2.007 \pm 0.010$ & $1.898-2.007$ & Summer \\
\hline 19. Breadth of metatarsus & $1.087 \pm 0.007$ & $1.061-1.087$ & Summer \\
\hline 20. Length of fourth tergite & $1.926 \pm 0.015$ & $1.841-1.926$ & Summer \\
\hline 21. Breadth or wax mirror & $2.030 \pm 0.035$ & $1.939-2.030$ & Autumn \\
\hline 22. Breadth of sixth sternite & $2.638 \pm 0.036$ & $2.531-2.638$ & Rainy \\
\hline
\end{tabular}

S.E. = Standard error about mean; R.V. = Range of variation.

All the mean values are in $\mathrm{mm}$ except wing venation angles which are in degrees.

\section{A) Tongue}

Tongue length showed no significant differences in the bee samples collected during different seasons.

\section{B) Antenna}

Length of flagellum and antenna $(F=4.400$ and 10.263 respectively, d.f. $5,174, \mathrm{P}<0.01$ ) were significantly different in bee samples collected during different seasons, whereas, no significant differences existed in the length of scape and pedicel. 
Further, multiple means comparison by $t$ test revealed that length of flagellum and antenna was significantly greater in summer and autumn season bees than those collected in other seasons $(P<0.01)$. However, bee samples collected during rainy season showed significantly higher values for the length of flagellum as compared to late winter season bees $(\mathbf{P}<0.05)$.

\section{C) Fore wing}

Different parameters of fore wing such as length of fore wing, radial cell, wing venation angle numbers 31 and $34(F=26.841,11.486,3.289$ and 4.217 respectively, d.f. $5,174, \mathrm{P}<0.01$ ) showed significant differences in bees collected during different seasons. All other characters of fore wing did not show any significant differences among bee samples collected in different seasons.

$t$ test analysis showed that summer and autumn season bees had significantly longer fore wings and radial cells than those collected in other seasons $(P<0.01)$. Further, rainy and spring season bees showed significantly longer fore wings than those collected during winter season $(\mathrm{P}<0.01)$. Similarly, spring season bees also showed significantly higher mean values for radial cell than winter season bees $(\mathrm{P}<0.05)$.

Means values of wing venation angle numbers 31 and 34 were significantly smaller in rainy and winter season bees as compared to autumn season bees $(\mathrm{P}<0.01)$. Further, winter season bees showed significantly lower value of angle number 31 than summer season bees $(P<0.05)$, whereas, mean value of angle number 34 was significantly bigger in spring season bees than those collected in summer $(\mathrm{P}<0.01)$, rainy $(\mathrm{P}<0.01)$ and winter seasons $(\mathrm{P}<0.01)$.

\section{D) Hind wing}

Significant differences were observed in the breadth of hind wing, length of veins VL and IL and vannal lobe $(\mathrm{F}=3.147,3.125,19.769$ and 11.214 respectively, d.f. $5,174, \mathrm{P}<0.01$ ) in bee samples collected during different seasons, whereas, other parameters of hind wing did not show any significant difference.

Multiple means comparison by $t$ test of different characters of hind wing showed that breadth of hind wing, length of veins VL and IL and vannal lobe was significantly greater in summer and autumn season bees as compared to bee samples collected in other seasons $(\mathrm{P}<0.01)$. Further, breadth of hind wings and length of vannal lobe showed significantly smaller values in rainy and late winter season bees than in spring season bees $(P<0.05)$. Length of veins $V L$ and IL was significantly smaller in rainy and late winter season bees than in spring season bees $(\mathrm{P}<0.05)$. Length of veins $\mathrm{VL}$ and IL was significantly 
shorter in spring season bees as compared to those collected in early winter season $(P<0.05)$.

\section{E) Hind leg}

Length of femur and tibia showed significant differences in bees collected during different seasons of the year $(F=7.758$ and 6.891 respectively, d.f. $5,174, \mathrm{P}<0.01$ ) whereas, no significant differences were observed in the length and breadth of metatarsus.

$t$ test analysis indicated that length of femur and tibia was significantly greater in summer and autumn season bees as compared to those collected in other seasons $(\mathrm{P}<0.01)$. Early winter season bees showed significantly higher value for length of femur than rainy and late winter season bees $(P<0.05)$, whereas, winter season bees had significantly shorter tibia than spring season bees $(\mathbf{P}<0.05)$.

\section{F) and G) Tergites and sternites}

Significant differences were observed in the length of third tergite $(\mathrm{F}=$ 19.520 , d.f. $5,84, \mathrm{P}<0.01$ ) ; length of wax mirror and distance between wax mirrors $(\mathrm{F}=3.217$ and 3.137 respectively, d.f. $5,84, \mathrm{P}<0.05)$ and length of third and sixth sternites $(\mathrm{F}=5.420$ and 5.293 respectively, d.f. 5,84, $\mathrm{P}<0.01$ ) in bee samples collected during different seasons. However, no significant differences were noted in other characters.

Further, $t$ test analysis revealed that summer and autumn season bees had significantly longer third tergite and third and sixth sternites than other bee populations $(\mathrm{P}<0.01)$, but winter season bees showed significantly smaller values for those characters as compared to spring season bees $(P<0.05)$. Length of wax mirror was significantly more in autumn season bees as compared to spring, winter and rainy season bees $(P<0.01)$, whereas, winter and rainy season bees had significantly less broader wax mirrors than summer season bees $(\mathrm{P}<0.01)$. However, distance between wax mirrors showed significantly higher values for summer season bees as compared to bee samples collected during other seasons $(\mathrm{P}<0.01)$.

\section{DISCUSSION}

Present investigations indicated that seasonal variations affect a large number of morphological characters of A.c. indica (tables 1,2). These results corresponded well with the earlier work on $A$. mellifera. Statistical analysis of the present 
biometrical data showed that length of fore wing and third tergite increased significantly towards the end of summer, whereas, number of hooks did not differ significantly in various seasons. MichaILov (1927) also reported similar results for $A$. mellifera. He also indicated significant seasonal changes in tongue length and breadth of fore wing but these were not observed in the present investigations. Gromisz (1962) and AnTONTSEva (1975) reported that the length of fore wings increased in worker bees of $A$. mellifera from spring till summer and then decreased towards autumn season and similar trend was also observed in the present investigations. Like $A$. mellifera, length of fore wing, wax mirror and third sternite of $A$.c. indica also showed significantly higher values for samples collected during summer than rainy season but no significant differences were found in tongue length, length of fourth tergite and width of fore wing as reported by Mizis (1976). Present morphometric results on A.c. indica also supported the observations of Dianov (1977) who also reported significantly greater size of fore wing, femur, tibia and third tergite in $A$. mellifera samples collected in autumn than in spring season.

Present studies on A.c. indica indicate that for racial investigations, the material should be taken at the same time of annual cycle. As the bee samples collected during summer and autumn seasons were bigger in size as compared to other seasons, so it is suggested that for racial investigations, the samples should be collected in summer and autumn seasons.

Received for publication in October 1983. Accepted for publication in March 1984.

\section{ACKNOWLEDGEMENTS}

The authors are thankful to Prof. H.O. Agrawal, Head, Department of Bio-Sciences, Himachal Pradesh University for providing the necessary laboratory facilities to carry out the present investigations. One of authors is grateful to Himachal Pradesh University for providing the necessary financial assistance in the form of fellowship.

\section{RESUME}

ETUDE MORPHOMETRIQUE DE L'ABEILLE INDIENNE, APIS CERANA INDICA F. INFLUENCE DES VARIATIONS SAISONNIERES

Des études morphométriques réalisées sur des échantillons d'abeilles ouvrières, prélevées aux diverses saisons, ont montré que de nombreux caractères morphologiques présentaient des valeurs significativement plus élevées dans les échantillons prélevés en été ou en automne, par rapport à ceux prélevés au cours des autres saisons. C'est le cas des caractères suivants : longueur du flagelle, de l'antenne, de l'aile antérieure, de la cellule radiale, des veines alaires VL et IL, du 
lobe vannal, du fémur, du tibia, du $3^{\circ}$ tergite, du miroir à cire, des $3^{e}$ et $6^{e}$ sternites et largeur de l'aile postérieure.

Pourtant d'autres caractères (longueur de la langue, du scape, de l'aile postérieure, du métatarse, largeur de l'aile antérieure, de la cellule radiale, etc.) n'ont pas montré de différence significative en fonction de la saison. L'été et l'automne sont, dans cette région, les périodes de forte miellée et il semble que la force de la colonie et la présence de nourriture larvaire en excès affectent la biométrie d'Apis cerana indica.

\section{ZUSAMMENFASSUNG}

\section{MORPHOMETRISCHE UNTERSUCHUNGEN ÜBER DIE INDISCHE HONIGBIENE, APIS CERANA INDICA F. EFFEKT DER SAISONALEN VARIATION}

Die Effekte der saisonalen Variation auf die Biometrie von Apis cerana indica wurden durch Entnahme von Bienenproben im Sommer, zur Regenzeit, im Herbst, frühen Winter, späten Winter und Frühling untersucht. Jede Probe bestand aus 15 markierten Arbeitsbienen gleichen Alters und aus einem Volk. Die Bienen wurden mit Chloroform betäubt, in heißem Wasser getötet und in «Pampell's fixative» aufbewahrt. Die Messungen wurden mit einem Stereomikroskop mit Meßskala durchgeführt. Die verschiedenen Winkel zwischen den Flügeladern wurden mit Hilfe eines Diaprojektors aufgezeichnet und gemessen.

Es wurden 39 morphometrische Merkmale der Zunge, der Antennen, des Vorderflügels, des Hinterflügels, des Hinterbeins, der Tergite und Sternite (Abb. 1, 2) untersucht. Die als Signifikanztest durchgeführten statistischen Analysen waren: einfache Varianzanalyse und T-Test.

Die morphometrischen Untersuchungen zeigten, $\mathrm{da} B$ viele morphologische Merkmale wie Länge der Geißel, Antenne, Vorderflügel, Radialzelle, Flügeladern VL und IL, Analfeld, Femur, Tibia, 3. Tergit, Wachsspiegel, 3. u. 6. Sternit und die Breite des Hinterflügels signifikant höhere Werte bei Sommer- und Herbstbienen aufweisen als bei den Bienen der anderen Jahreszeiten (Tab. 1). Gleichwohl zeigten andere morphologische Merkmale wie Rüssellänge, Schaftlänge, Länge des Hinterflügels, Metatarsuslänge, Breite des Vorderflügels, Radialzelle usw. keine signifikanten Unterschiede bei den Proben der verschiedenen Jahreszeiten (Tab. 2).

Sommer und Herbst sind die ergiebigsten Trachtzeiten in dieser Region und es scheint, daß die Koloniestärke und ein Ubberflu $\beta$ an Futter für die Larven die Biometrie von Apis cerana indica beeinflussen.

\section{REFERENCES}

AtPatov W.W., 1929. - Biometrical studies on variation and races of the honeybee (Apis mellifera L.). Quart. Rev, Biol., 4, 1-58.

ANtontseVa P.V., 1975. - Seasonal changes in external characters of local bees of the Dzhungarskii Alatau (mountains). Temat. Sborn. Nauch. Trud. Alma - Atin i Semipal. Zoovet. Institov, 36, 31-32.

Dianov P.A., 1977. - Chronographic variability of parameters of honeybees from the mountainous zone of Kazakhstan. Izv. Akad. Nauk. Kazak. Biol., 1, 38-40.

Gromisz M., 1962. - Season variations of wing measurements and cubital index of honeybee (Apis mellifera L.). Pszczel. Zesz. Nauk., 6, 113-120.

KAPIL R.P., 1956. - Variations in the biometrical characters of the Indian honeybee (Apis indica F.). Indian J. Entomol., 18, 440-457. 
KSHIRSAGar K.K., 1981. - Morphometric studies on Apis cerana indica F. Worker, 1II. Effect of geographical position on morphometric characters. Indian Bee J., 43, 1-5.

MichaIlov A.S., 1927. - Über die Saison - Variabilität der Honigbiene. Arch. Bienenkd,, 8, 16-24.

Mizis A.P., 1976. - External morphological characters of the Lithuanian honeybee and their correlation variability. Proc. Int. Symp. on Bee Genetics, Selection and Reproduction, Moscow, 153-156.

RuttNer F., 1976. - Isolated populations of honeybees in Australia. J. apic. Res., 15, 97-104.

Ruttner F., Tassencourt L., Louveaux J. 1978. - Biometrical-statistical analysis of the geographic variability of Apis mellifera L. 1. Material and Methods. Apidologie 9, 363-381.

Snedecor G.W., Cochran W.G., 1976. - Statistical methods. New Dalhi: Oxford and IBH publishing company. 